\title{
Bolesław Kumor
}

\section{Granice archidiecezji gnieźniejskiej w tysiącleciu (1000-1939)}

Prawo Kanoniczne : kwartalnik prawno-historyczny 9/3-4, 3-26

1966

Artykuł został zdigitalizowany i opracowany do udostępnienia w internecie przez Muzeum Historii Polski w ramach prac podejmowanych na rzecz zapewnienia otwartego, powszechnego i trwałego dostępu do polskiego dorobku naukowego i kulturalnego. Artykuł jest umieszczony w kolekcji cyfrowej bazhum.muzhp.pl, gromadzącej zawartość polskich czasopism humanistycznych i społecznych.

Tekst jest udostępniony do wykorzystania w ramach dozwolonego użytku. 


\begin{tabular}{lllllllllllllllll}
$\mathbf{R}$ & $\mathbf{O}$ & $\mathbf{Z}$ & $\mathbf{P}$ & $\mathbf{R}$ & $\mathbf{A}$ & $\mathbf{W}$ & $\mathbf{Y}$ & $\mathbf{I}$ & $\mathbf{A}$ & $\mathbf{R}$ & $\mathbf{T}$ & $\mathbf{Y}$ & $\mathbf{K}$ & $\mathbf{U}$ & $\mathbf{L}$ & $\mathbf{Y}$ \\
\hline
\end{tabular}

Prawo kanoniczne

$9(1966)$ nr 3-4

\author{
KS. BOLESEAW K U M O R
}

\title{
GRANICE ARCHIDIECEZJI GNIEZNNIENSKIEJ W TYSIĄCLECIU (1000-1939)
}

1. Granice archidiecezji w okresie przedrozbiorowym (do 1772 r.) a) Dotychczasowe opracowania tematu. b) Początki archidiecezji i jej pierwotne granice. c) Uformowanie się stałych granic archidiecezji w XIII-XIV w. d) Ostatnie zmiany graniczne przed 1772 r. 2. „Rozbiory” archidiecezji $i$ formowanie nowego jej terytorium a) Geneza zmian terytorialnych i zmiana granic w latach 1772-1315. b) Uformowanie nowego terytorium archidiecezji $i$ jej granic $w$ latach 1915-1821. 3. Zmiany granic archidiecezji w latach 1918-1939. a) Plany i zmiany granic archidiecezji w latach 1918-1939. b) Statystyka

\section{Granice archidiecezji w okresie przedrozbiorowym (do 1772 r.).}

\section{a) Dotychczasowe opracowania tematu.}

Artykuł niniejszy stawia sobie za cel przedstawienie wszystkich zmian $w$ granicach archidiecezji gnieźnieńskiej, jakie na przestrzeni tysiąclecia formowały jej terytorium. Górna granica czasowa artykułu sięga początków archidiecezji tj. r. 1000, podczas gdy dolna opiera się na dacie wybuchu drugiej wojny światowej (1939). Data ta, chociaż posiada charakter umowny, jest o tyle ważna, że przed r. 1939 miały miejsce ostatnie $\mathrm{z}$ dotychczasowych zmiany $w$ granicach archidiecezji. Pod względem rzeczowym artykuł omawia granice archidiecezji, a nie metropolii gnieźnieńskiej, przy czym zajęto się granicami jej terytorium, a nie wewnętrznym podziałem administracyjnym.

Celem rzetelnego udokumentowania artykułu autor starał sie dotrzeć przede wszystkim do dokumentów papieskich, ponieważ zgodnie $z$ założeniami prawa kościelnego tylko papież może decydować o granicach diecezji; założenie powyższe udało się 
zrealizować prawie w 90\%. W rezultacie takiej zasady artykuł został oparty zasadniczo na źródłach drukowanych i archiwalnych. $\mathrm{Z}$ literatury pomocniczej przedmiotu zacytowano $\mathrm{z}$ obowiązku bibliograficznego tylko ważniejsze opracowania. Trzeba też zaznaczyć, że właściwej literatury przedmiotu nie ma. Oprócz kilku hipotez, dotyczących najdawniejszych granic archidiecezji, tylko ks. Korytkowski podał we wstępie do „Arcybiskupów... gnieźnieńskich" garść informacji na ten temat, przy czym bardziej szczegółowo omówił zmiany graniczne tylko w XIV w., podczas gdy prawie całkowicie pominął wiek XVIII i XIX. Autor bowiem zajął się omówieniem przede wszystkim wewnętrznej organizacji archidiecezji (archidiakonaty, dekanaty, parafie) i jej instytucji (kolegiaty, opactwa, prepozytury, klasztory), natomiast mniej poświęcił miejsca problemom granicznym '. Artykuł Hoffmana rozważa tylko te zagadnienia, jakie złożyły się na genezę i wykonanie bulli De salute animarum z 16 VII $1821^{2}$. Z ważniejszych prób kartograficznych należy wymienić prace Korytkowskiego, Warężaka dla XVI w., Jabczyńskiego dla XIX w. (po r. 1821) i Beckmanna ${ }^{3}$; ostatnia $z$ wymienionych pozycji stanowi pierwszą próbę podania ważniejszych zmian $\mathrm{w}$ granicach archidiecezji w XIX i XX w.

Historiografia polska zna tego rodzaju prace, ale dotyczą one $z$ reguły administracji państwowej ${ }^{4}$. $Z$ opracowań dotyczących

1 Korytkowski J., Arcybiskupi gnieźnieńscy, prymasowie $i$ metropolici polscy od r. 1000 az do r. 1821, Poznań 1888, t. I s. 29-39. Art. przygotowano do druku w $1964 \mathrm{r}$.

2 H of $\mathrm{fm}$ a n B., Wykonanie bulli, ,De salute animarum $w$ W. Ks. Poznańskim. „Roczniki Historyczne" VIII/1932 s. 22-58, 116-196.

${ }^{3}$ K or ytkowski J., Mapa archidiecezji gnieźnieńskiej $w$ XV $w$, W: E a s ki J., Liber beneficiorum archidioecesis Gnesnensis. Ed. J. Eukowski, Poznań 1880, t. II (przy końcu); W a r ęż a k J., Mapa uposażenia arcybiskupstwa gnieźnieńskiego w wiekach średnich, W: Tenże, Rozwój uposażenia arcybiskupstwa gnieźnieńskiego $w$ średniowieczu, Lwów 1929; J a b cz yńs ki J., Mapa archidiec. gnieźnieńskiej i poznańskiej, Poznań 1838; B e c k man n J., s. v. Gnesen und Posen, W: LThK Bd IV(1932) s. 553--554.

${ }_{4}$ Por. A rnold A., Terytoria plemienne $w$ ustroju administracyjnym Polski Piastowskiej (w. XII-XIII) Prace Komisji dla Atlasu Hist. Polski, Kraków 1927, z. 2, s. 1-126; M. B i s k u p i A. T o m c z a k, Mapy wojew. pomorskiego $w$ drugiej polowie XVI $w$. I Rozmieszczenie własności ziemskiej. II Sieć parafialna, Toruń 1955. Roczniki Tow. Nauk. W Toruniu LVIII(1953), z. 1; Woj c i e chowski Z., Momenty terytorialne organizacji grodowej $w$ Polsce Piastowskiej, Lwów 1924; Tenże, Ze studiów nad organizacja państwa polskiego za Piastów, Lwów 1924; Z Z ją c z k o w s k S., Uwagi nad terytorialno-administracyjnym nym ustrojem Polski XII w. „Czasopismo Historyczno-Prawne” VII(1955) z. 1 . 
historycznej geografii kościelnej, należy wymienić jedynie niemieckie prace poświęcone granicom diecezji kamieńskiej, warmińskiej i wrocławskiej ${ }^{5}$, oraz w jezzyku polskim artykuł Potkańskiego o granicach diecezji krakowskiej (w średniowieczu) i podpisanego dla diecezji tarnowskiej i kieleckiej ${ }^{6}$.

Już na wstępie należy zaznaczyć, że ogromna większość zmian granicznych $\mathrm{w}$ stanie posiadania archidiecezji miała swe zasadnicze źródła w procesach o charakterze politycznym. Tak było $w$ średniowieczu (pogranicze $z$ diecezją kamieńską), a zwłaszcza w okresie rozbiorowym 1772-1821. U podstaw tylko niektórych przesunięć granicznych leżały przyczyny natury ekonomicznej (1764), czy duszpasterskiej (1925). Trzeba też zaznaczyć, że podczas gdy w średniowieczu poszczególne przesunięcia graniczne (oprócz sporu o kasztelanię słupską) miały na celu najczęściej dokładne wytyczenie granic archidiecezji, to zmiany $w$ okresie rozbiorowym dały $w$ rezultacie duże zmniejszenie jej terytorium, a powiększenie jej kosztem innych diecezji (Włocławek, Kielce, Warszawa, Sandomierz).

\section{b) Poczqtki archidiecezji $i$ jej pierwotne granice.}

$\mathrm{Na}$ podstawie współczesnych przekazów źródłowych przyjmuje się, że fundacja i erekcja archidiecezji gnieźnieńskiej nastąpiła w latach 999/1000 za pontyfikatu pap. Sylwestra II i Bolesława Chrobrego ${ }^{7}$. Odmienne i odosobnione stanowisko zajmuje G. Labuda; przyjmuje on mianowicie, że do r. 1000

5 Wiesener W., Die Grenzen des Bisthumus Cammin, „Baltische Studien" XLIII(1893) s. 117-127; S a g e J., Die Grenzen des ermländischen Bisthumssprengels seit dem XIII Jahrhundert. „Zeitschrift für Geschichte und Alterthumskunde Ermlands" Jhrg 1858/60 Bd I, H. 1/3, s. 40-92; J u n g n it z J., Die Grenzen des Breslauer Bistums, W: Darstellungen und Quellen zur schlesische Geschichte, Wroclaw 1907, t. III, s. 1-18.

6 P otkański K., Granice $\overrightarrow{~ b i s k u p s t u a ~ k r a k o w s k i e g o, ~ „ R o c z n i k ~}$ Krakowski" IV(1900), s. 201-232; K u m or B., Dzieje polityczno-geograficzne diecezji tarnowskiej, Lublin 1958; Tenże, Organ. teryt. diec. kieleckiej. „Nasza Przeszłość”, T. XVII(1963), s. 187-232.

${ }^{7}$ Kronika Thietmara, Wyd. M. Z. Jedlicki, Poznań 1953, s. 206 oraz MPH t. I, s. 259; Rocznik Krakowski p. r. 1000, W: MPH t. II, s. 162; Rocznik świętokrzyski dawny p. r. 1000, W: MPH t. II, s. 773; Rocznik kapituły krakowskiej p.r. 999, W: MPH t. II, s. 793; por. K oz 1 ow s$\mathrm{k}$ a - B u dk ow a Z., Repertorium polskich dokumentów doby piastowskiej, Kraków 1937, z. 1, nr 4 s. 5-6 gdzie podano literaturę tematu. Nowsze pozycje zob. Now acki J., Dzieje archidiecezji poznańskiej, Poznań 1959, t. I, s. 1-52. 
,,jedyne w Polsce biskupstwo od 968 r. było w Gnieźnie" 8. Za Gnieznem miały przemawiać: powstanie pierwszej bazyliki, złożenie zwłok św. Wojciecha i utworzenie arcybiskupstwa dla całej Polski, te zaś ostatnie tworzono „w najwybitniejszych ośrodkach życia politycznego i kulturalnego". Hipoteza ta jednak nie przyjęła się w nauce polskiej ${ }^{9}$.

Ze względu na brak dokumentu fundacyjnego i erekcyjnego archidiecezji wszelkie ustalanie pierwotnych jej granic będzie zawsze hipotetyczne, chociaż można prawdopodobnie przyjąć, że $z$ chwilą erekcji otrzymała ona granice stałe ${ }^{10}$. Wprawdzie ,granic nowoutworzonych diecezji (w r. 1000) oznaczyć dokładnie niepodobna, nie mniej trzeba zgodzić się z Abrahamem, Schmidem i Potkańskim, że pierwotne granice archidiecezji $\mathrm{i}$ innych diecezji polskich pokrywały się $z$ granicami osadniczymi, plemiennymi i politycznymi ${ }^{11}$. Według Abrahama archidiecezja gnieźnieńska w XI w. obejmowała $\mathrm{m}$. in. część Wielkopolski i ,ziemie mazowieckie, z których później powstał archidiakonat warszawski", przy czym jej granice wschodnie pozostawały otwarte ${ }^{12}$. Korytkowski sądzi, że we skład ówczesnej archidiecezji weszły „wschodnia część Wielkopolski... i pólnocna część Pomorza na zachód (Autor - „na wschód”) od rzeki Brdy... aż do Bałtyku sięgając, obejmując tak zwaną kasztelanię słupską z głównym miastem Słupsk" ${ }^{13}$. Ostatnio Nowacki przyjmuje, że pierwotny obszar archidiecezji rozciągał się na „wschodnią część Wielkopolski, Kujawy, Łęczyckie, Sieradzkie i rozległe strefy Mazowsza" ${ }^{4}$ i jeszcze w XI w.

${ }^{8} \mathrm{La}$ a uda G., Studia nad poczatkami państwa polskiego, Poznań 1946, s. 205 nn., 236.

${ }^{9}$ Por. Historia Polski. Red. H. Eowmiański. T. I cz. 1 (do połowy XV w.), Warszawa 1957, s. 191.

10 Por. Abraham W., Organizacja Kościcla $w$ Polsce do potowy $X I I$ w., wyd. II, Lwów 1893, s. 56.

11 Tamże, s. 60; Schmid H. F., Die rechtlichen Grundlagen der Pfarrorganisation auf westslavischem und ihre Entwicklung während des Mittelalters, Weimar 1938, s. 178 n.; P otk ańs ki K., Granice biskupstwa krakowskiego, Kraków 1900, s. 26.

${ }_{12}$ A b r a ha m W., op. cit., s. 61 n.; Ostatnio ks. Nowacki postawił hỉpotezę, że przed r. 1124 nie należała do archidiecezji gnieźnieńskiej Ziemia kaliska, lecz do poznańskiej, zob. N o w a ck i J., Archidiecezja poznáska w granicach historycznych i jej ustrój, Pozná́ $1965 \mathrm{~s} .9$.

${ }^{13} \mathrm{~K}$ or y tk ow sk i J., Arcybiskupi gnieźnieńscy, prymasowie $i$ metropolici polscy od r. 1000 aż do r. 1821, Poznań 1888, t. I, s. 30.

${ }^{14} \mathrm{~N}$ ow a cki J., Dzieje archidiecezji poznańskiej, Poznań 1959, t. I, s. 44. 
został zmniejszony $w$ rejonie Kujaw na rzecz nowotworzonego biskupstwa kujawskiego" ${ }^{15}$.

Znane $z$ późniejszych przekazów źródłowych granice archidiecezji zostały ustalone prawdopodobnie w pierwszej połowie XII w. Już w r. 1075 pap. Grzegorz VII w liście apostolskim Quoniam honor, qui ministris, zaadresowanym na ręce Bolesława Smiałego, domagał się reorganizacji Kościoła w Polsce i nowego podziału terytorialnego; skarży się bowiem, że w Polsce „,jest zbyt mało biskupów, a ich diecezje są bardzo rozległe" ${ }^{16}$. Istnieją natomiast pewne przekazy źródłowe $z$ pierwszej połowy XII w., że nowe granice przynajmniej dla niektórych diecezji polskich wyznaczył kard. Idzi z Tuskulum, bawiący w Polsce w charakterze legata pap. Kaliksta II w latach $1123 / 25{ }^{17}$. Otóż pap. Eugeniusz III w bulli protekcyjnej dla diecezji włocławskiej Quoties illud a nobis petitur z 5 IV 1148 r. zatwierdził granice ,tejże diecezji... jakie zostały wyznaczone przez Idziego biskupa Tuskulum i księcia Bolesława" ${ }^{18}$. Niektórzy badacze naukowi przyjmują, że i archidiecezja gnieźnieńska otrzymała wówczas nowe granice. I tu Abraham przypuszcza, że wówczas przyłączono do Gniezna tytułem rekompensaty za utworzenie biskupstwa we Wlockawku, terytoria małopolskie $w$ bulli w r. 1136 wymienione" ${ }^{19}$. Były to tereny późniejszego archidiakonatu kurzelowskiego, leżące na południe od rzeki Pilicy w granicach Małopolski. Wedlug Nowackiego w r. 1124 ,,rozszerzono... granice archidiecezji gnieźnieńskiej o obszary na północ od Noteci poprzez Chojnice, Człuchów i Słupsk aż do

${ }^{15}$ A br a h a m W., op. cit., s. 65; Now a cki J., op. cit., t. I, s. 48; Górski K., Topografia wczesnośredniowiecznej Kruszwicy, ,Studia Wczesnośredniowieczne", II(1953)55 przyjmuje, że biskupstwo kujawskie było dalszym ciągiem biskupstwa kołobrzeskiego, a czas przeniesienia rezydencji biskupów kołobrzeskich na Kujawy ustala na panowanie Mieszka II. Ostatnio natomiast J. T a z b i r o w a, Początki biskupstwa na Kujawach, „Przegląd historyczny” 53 (1962), z. 2, s. 234 przyjmuje, że biskupstwo na Kujawach (Kruszwica) ufundował Mieszko II, zaś dopiero w latach $1123 / 25 \mathrm{kard}$. Idzi dokonał erekcji drugiego biskupstwa we Włocławku (s. 238), do którego przyłączył tereny biskupstwa kruszwickiego.

16 MPH t. I, s. $367 \mathrm{n}$.

17 MPH II s. 13-14; K o złow s k a - B udkow a Z., op. cit., s. 52 n., $\mathrm{nr}$ 47; $\mathrm{H}$ e y $\mathrm{n}$ e J., Dokumentirte Geschichte des Bisthums und Hochstiftes Breslau, Wrocław 1860 , t. I, s. 166.

${ }_{18} \mathrm{MPH}$ t. II, s. 13 n.; K O złow ska-B u dk ow a Z., op. cit., s. 52 n., nr 47. s. 22.

${ }_{19}$ A braham W., op. cit., s. 65; por. Pontkański K., op. cit. 
Bałtyku" 20. Jednakże ta ostatnia hipoteza jest mało prawdopodobna, przeciwko niej bowiem przemawiają współczesne dokumenty, o czym nieco niżej.

Najdawniejszym przekazem źródłowym informującym ubocznie o granicach archidiecezji jest bulla protekcyjna pap. Innocentego II Ex commisso nobis a Deo z 7 VII $1136 \mathrm{r}$. Wprawdzie bulla ta nie podaje granic archidiecezji, nie mniej obszar powinności dziesięcinnych zakreśla jej rozległość. 'W skład archidiecezji według tejże bulli wchodziły następujące kasztelanie: gnieźnieńska, ostrowska, łekneńska, nakielska, lądzka, kaliska, czestramska nad Baryczą, część kasztelanii milickiej, sieradzka, spicimierska, małogoska, rozpierska, łęczycka, wolborska, żarnowska, skrzyńska i łowicka. Obszar tedy archidiecezji odpowiadał w ogólnym rzucie jej późniejszym granicom i jak podaje Warężak obejmował $40.100 \mathrm{~km}^{2} 21$.

Powodzenia Polski na odcinku polityki pomorskiej wpłynęły bezpośrednio jeszcze $\mathrm{w}$ XIII $\mathrm{w}$. na rozszerzenie granic archidiecezji w kierunku Bałtyku przez przyłączenie doń części Pomorza wraz z kasztelanią słupską. Nie stało się to jednakże w pierwszej połowie XII w., jak chce Nowacki ${ }^{22}$. Bulla bowiem protekcyjna dla biskupstwa kamieńskiego $E x$ commiso nobis a, Deo z 14 X 1140 r., wydạna przez pap. Innocentego II, zakreśla wschodnie granice tegoż biskupstwa aż do rzeki Łeby ${ }^{23}$, podczas gdy bulla protekcyjna dla Gniezna z r. 1136 nie wymienia żadnych posiadłości arcybiskupstwa na Pomorzu ${ }^{24}$. Pierwsze ślady jurysdykcji Gniezna na tych terenach pochodzą z pierwszej połowy XIII w. Przejęcie jurysdykcji kościelnej przez Gniezno w kasztelanii słupskiej była zapewne następstwem wzmożonej akcji arcybiskupów gnieźnieńskich, zmierzającej do podporządkowania diecezji kamieńskiej swej

20 N ow a ck i J., op. cit., t. I, s. 44.

21 KDWP t. I nr 7 s. 10-14; W a r ęż a k J., Rozwój uposażenia arcybiskupstwa gnieźnieńskiego w sredniowieczu, Lwów 1929, s. $7 \mathrm{n}$.

$22 \mathrm{~N}$ o w a c ki J., op. cit., t. I, s. 44.

${ }^{23}$ MPH t. II, s. 19 n. przyp. 2; K o z $10 \mathrm{wska}-\mathrm{Budk}$ owa Z., op. cit. s. 41 n. nr 37; por. Wì s e n e $\mathrm{r}$ W., Die Grenzen des Bisthums Cammin, „Baltische Studien”, 43(1893)117; S a 1 i s, F., Forschungen zur älteren Geschichte des Bisthums Kammin, „Batlische Studien”, 26 N. F. (1924) 33 n.; B a h r E., Die Verwaltungsgebiete Königlich-Preussen 1454-1772, „Zeitschrift des Westpreussischen Geschichtsvereins", 74(1938)132; H ey de $\mathrm{n} \mathrm{H.,} \mathrm{Kirchengeschichte} \mathrm{Pommerns,} \mathrm{Aufl.} \mathrm{2,} \mathrm{Köln}$ 2, Köln 1957, t. I, s. 31; H a u c k, A., Kirchengeschichte Deutschlands, Aufl. 8, Berlin-Leipzig 1954, t. IV s. 609.

24 W a r ęż a k J., op. cit., s. 20. 
-

zwierzchności metropolitarnej ${ }^{25}$ i politycznych zmian, jakie miały miejsce w tym rejonie (Słupek, Sławno) po wygaśnięciu Raciborowiców (1227), kiedy to Sławno i Słupsk zostały zagarnięte przez księcia Pomorza Gdańskiego, Swiętopełka II i jego syna Mszczuja II ${ }^{26}$.

c) Uformowanie statych granic archidiecezji $w X I I I-X I V w$.

W związku ze zmienioną sytuacją polityczno-kościelną biskup kamieński, Konrad III, zwrócił się Stolicy Apostolskiej $z$ prośbą nie tyle o zatwierdzenie egzempcji swego biskupstwa, ile raczej ze skargą $\mathrm{m}$. in. na arcybiskupa gnieźnieńskiego, naruszającego granice jego diecezji. W odpowiedzi na to pap. Grzegorz IX listem apostolskim Sua nobis venerabilis $\mathrm{z}$ dnia 20 III 1236 r. zlecił legatowi Wilhelmowi rozpatrzeć sprawe oderwania od diecezji kamieńskiej niektórych obszarów na rzecz archidiecezji gnieźnieńskiej ${ }^{27}$. Wyroku legata nie znamy. Gniezno utrzymało jurysdykcje na terenie kasztelanii słupskiej w XIII w. (Dokum. z dn. 27 III 1240), chociaż przejściowo ok. 1273 r. przeszła ona w ręce biskupów kamieńskich ${ }^{28}$. Dopiero odkąd Mszczuj II (†1294) przekazał Pomorze Gdańskie wraz z kasztelanią słupską Przemysłowi II z Wielkopolski prawa jurysdykcyjne Gniezna zostały znów w pełni zagwarantowane. I tak, kiedy 29 VI 1284 r. Mszczuj II przelał prawa patronatu do kościoła św. Stanisława w Gardzie Wielkiej na klasztor w Białobuku i proboszcza św. Mikołaja w Słupsku, uczynił to za zgodą arcybiskupa gnieźnieńskiego, Jakuba Swinki ${ }^{29}$. Trzy dalsze dokumenty $z$ lat $1293 / 94$ świadczą o przynależności tych terenów do archidiecezji gnieźnieńskiej ${ }^{30}$. W r. 1299 w Słupsku była siedziba archidiakona Andrzeja Kopydłowicza, ustanowionego tu z ramienia Gniezna ${ }^{31}$. Co więcej, jak wynika

${ }_{25} \mathrm{Walicki} J .$, Przynależność metropolitalna biskupstwa kamieńskiego $i$ lubuskiego na tle rywalizacji Magdeburga $i$ Gniezna, Lublin 1960, s. $78 \mathrm{nn}$.; Hey den H., op. cit., t. I, s. 30; Gromnicki T., Swiętopietrze $w$ Polsce, Kraków 1908, s. $126 \mathrm{nn}$.

${ }^{26} \mathrm{~S}$ la ski K., Dzieje Ziemi Kolobrzeskiej do czasów jej germanizacji, Toruń 1948, s. 54; H. Heyden, op. cit., t. I, s. 30.

${ }_{27}$ PUB (Pommersches Urkundenbuch, t. I-IV, Szczecin 1868-1903)

t. I, $\mathrm{nr} 329$ s. 250.

${ }^{28} \mathrm{H}$ e y d e $\mathrm{n}$ H., op. cit., t. I, s. $30 \mathrm{n}$.

29 PUB t. II, nr 1307.

30 Tamże, t. III, nr 1680, 1690; por. H e y d e n H., op. cit., t. I, s. 31; $\mathrm{K}$ or y tkow s k i J, op. cit., t. I, s. $30 \mathrm{n}$.

31 PUB t. III, nr 1898; H e y d e $\mathrm{n}$ H., op. cit., t. I, s. 31 ; por. $\mathrm{K} \mathrm{o-}$ r y $\mathrm{tk}$ ow ski J., op. cit., t. I, s. 30 . 
z przekazów źródłowych pierwszego 20-lecia XIV w., na terenie Pomorza Słupskiego arcybiskup gnieźnieński utrzymywał dwóch archidiakonów,,pomorskich", z których jeden posiadał nawet godność biskupa in part. inf. i stąd nazywano go biskupem ,słupskim" 32 .

Sprawy jurysdykcji kościelnej w tym rejonie zmieniły się odkąd Wacław II zasiadł na tronie polskim. Jak wynika z dwóch dokumentów z lat 1304 i 1307 biskup kamieński, Henryk, przejściowo rozciągnął jurysdykcję kościelną na kasztelalanię słupską ${ }^{33}$, jednakże decydujące znaczenie dla dalszych praw Gniezna miały znów inne zmiany polityczne. W r. 1308 Waldemar i Jan margrabiowie brandenburscy zdobyli Pomorze wschodnie, z którego w r. 1309 część odstąpiono Krzyżakom. Skorzystał $z$ tego biskup kamieński Henryk i poparciu Krzyżaków „siłą zbrojną wydarł biskupowi Dominikowi (sufragan gnieźnieński dla Słupska) posiadłości kościelne i jurysdykcję duchowną w Ziemi Słupskiej sobie przywłaszczył" ${ }^{34}$. Powstały $\mathrm{w}$ ten sposób gwałtowny spór przedstawiono przed trybunal papieski. Jan XXII listem apostolskim Querelam gravem z 1 XI 1319 r. polecił biskupom włocławskiemu i chełmińskiemu, oraz dziekanowi kapituły włocławskiej jako delegatom apostolskim zbadanie i rozstrzygnięcie zatargu ${ }^{35}$. Wyroku ostatecznego Stolicy Apostolskiej nie znamy, ale jest rzeczą pewną, że archidiakonat pomorski wraz ze Słupskim archidiecezja straciła na zawsze, pozostając tylko przy późniejszych terenach archidiakonatu kamieńskiego.

$\mathrm{Na}$ pograniczu z diecezją poznańską zaszło do końca XV w. kilka przesunięć granicznych. Znane są bliżej okoliczności w jakich biskupi poznańscy oderwali od archidiecezji kasztelanię czestramską, leżącą nad dolną Baryczą. Wiadomo, że kasztelania ta jeszcze w r. 1136 należała do Gniezna ${ }^{\mathbf{3 6}}$, podczas gdy w r. 1510 znajdowała się w granicach diecezji poznańskiej ${ }^{37}$. Ostatnio Nowacki podaje, że proboszcz czestramski w r. 1442 pierwszy podniósł sprawę przynależności parafii

32 Por. Korytkowiski J., op. cit., t. I, s. 30 przyp. 1 .

${ }^{33}$ PUB t. IV, nr 2158, 2355.

${ }^{34} \mathrm{~K}$ or y tk ow k k J., op. cit., t. I, s. 30 n.; Wi es en er W., op. cit., s. 126 ; H e y d e n H., op. cit., t. I, s. 31 .

${ }_{35}$ VMPL (Vetera Monumenta Poloniae et Lithuaniae) t. I, $\mathrm{nr} 247$ s. 157; PUB t. V, nr 3302; por. K or y tkow sk i J., op. cit., t. I, s. 31; H. Heyden, op. cit., t. I, s. 31 .

${ }^{30}$ KDWP t. I, nr 7 s. 11; por. W a rężak J., op. cit., s. 7 przyp. 1.

${ }^{37}$ Liber beneficiorum dioecesis Posnaniensis. Ed. J. Nowacki, Poznań 1950, s. 118; por. Mapa. Diecezja poznańska w r. 1510 (Tamże). 
(9 wsi) do diecezji poznańskiej. 29 IV 1446 r. prymas Wincenty Kot za zgodą gnieźnieńskiej kapituły metropolitarnej wystawił dokument, mocą którego parafia Czestram została wcielona do diecezji poznańskiej ${ }^{38}$. $Z$ obszernej enklawy nad Baryczą pozostała przy archidiecezji tylko część kasztelanii milickiej z późniejszymi parafiami: Kobylin, Krotoszyn, Zduny i Sulmierzyce.

25 III 1361 r. sąd polubowny, złożony z Marcina archidiakona gnieźnieńskiego i Jana Falona kanonika, oraz Andrzeja archidiakona poznańskiego i Jana kustosza rozstrzygnął spór między Gnieznem a Poznaniem o parafie w Żoniu, Grylewie i Gołańczy, przysądzając je ze wszystkimi wsiami parafialnymi archidiecezji gnieźnieńskiej ${ }^{39}$. 25 VIII $1361 \mathrm{r}$. wyrok uprawomocnił Mikołaj kanclerz kapituły gnieźnieńskiej jako superarbiter, a 14 IX t.r. Hanko notariusz autoritate apostolica ${ }^{40}$. Wyrok ten atoli nie zakończył sporu. $15 \mathrm{~V} 1364 \mathrm{r}$. odbył się w Gnieźnie zjazd obydwu ordynariuszów z Gniezna i Poznania, na którym zawarto nowy układ, moca którego parafie w Żoniu, Grylewie, Gołańczy, Chojnie i Jaktorowie zostały wcielone do archidiecezji gnieźnieńskiej, podczas gdy kościoły parafialne w Margoninie, Opatówku, Gozdowie i Sulaszowie, a nadto wsie Kowalewo, Lipiny i Samocice miały odtąd należeć do diecezji poznańskiej ${ }^{41}$. Ale i tym razem nie był to koniec nieporozumień granicznych. Zostały one odnowione w r. 1367 chociaż dokumenty nie przekazały informacji o jakie parafie wznowiono spór. Wiadomo tylko, że $28 \mathrm{~V} 1367 \mathrm{r}$. za zgodą kapituł diecezjalnych arcybiskup gnieźnieński Jarosław i biskup poznański Jan powołali sąd polubowny w składzie Paszko wojew. poznański, Przecław wojew. kaliski, Wincenty kasztelan gnieźnieński i Janusz kasztelan kamieński w celu ostatecznego rozgraniczenia obydwu diecezji ${ }^{42}$. Wyroku nie znamy. Wiadomo tylko, że jeszcze $12 \mathrm{~V} 1368 \mathrm{r}$. arcybiskup Jarosław zamianował prokuratorów, którym polecił upomnieć sędziów polubownych, by ci wydali sprawiedliwy wyrok ${ }^{4: 3}$. Nieznaczne spory graniczne na odcinku sąsiedztwa z Pozna-

\footnotetext{
38 Now a cki J., op. cit., s. 32 przyp. 48.

30 KDWP t. I, nr 1460 s. 189 n.; por. Now a ck i J., op. cit., s. 34.

40 Tamże, nr 1461 s. 190 n., nr 1462 s. 191 n.; por. K or y t kows ki J., op. cit., t. I, s. $34 ; \mathrm{N}$ ow a c k i J., op. cit., s. 34 .

41 KDWP t. I, nr 1522 s. 248 n.; por. N o w a c k i J., op. cit., s. 3

42 Tamże, t. I, nr 1578 s. 297 n. (Poznañ). Zapewne i kapituła gnieźnieńska wystawila odpowiedni dokument. Oraz KDWP t. I, nr 1579 s. 298 n.; por. Now a c k i J., op. cit., s. 34 .

43 Tamże, t. I, nr 1598 s. 315.
} 
niem, podobnie jak i na pograniczu z diecezją włocławską miały miejsce w XV i XVI w., ale dotyczyły one najczęściej poszczególnych wsi, a tylko wyjątkowo nowoutworzonych parafii ${ }^{44}$. Tak w latach 1415-1418 toczył się spór między Gnieznem a Poznaniem odnośnie do przynależności diecezjalnej parafii Kaszewy, zaś w r. 1440 o parafie Mnich i Strzelce $z$ biskupem płockim. Podczas gdy parafia Kaszewy od 1469 pozostała przy archidiecezji, to dwie pozostałe parafie odpadły do diecezji poznańskiej ${ }^{45}$.

W tym samym okresie doszło do przesunięć granicznych na korzyść Gniezna na pograniczu z diecezją krakowską. W r. 1357 po lokacji nowego miasta w Krzepicach Kazimierz Wielki wybudował i udotował kościół parafialny, wydzielając nowolokowane miasto $z$ dawnej parafii $w$ Kłobucku, będącej $w$ granicach diecezji krakowskiej. Następnie zwrócił się w r. 1364 do biskupa krakowskiego Bodzanty o przydzielenie nowej parafii dziesięcin ze stołu biskupiego, ten jednakże odmówi prośbie królewskiej. Wówczas to parafię uposażył dziesięcinami ze stołu kapituły metropolitarnej arcybiskup Jarosław i równocześnie za zgodą króla rozciągnął jurysdykcję Gniezna nad Krzepicami. W następstwie tego archidiecezja gnieźnieńska przekroczyła na tym odcinku rzekę Liszwartę, która dotąd stanowiła granicę między dwoma diecezjami ${ }^{46}$.

W ten sposób zostało ukształtowane takie terytorium archidiecezji, jakie znamy z Księgi uposażenia Łaskiego i map, sporządzonych przez Korytkowskiego i Warężaka ${ }^{47}$. Według tych przekazów najdalej wysuniętych na północ punktem archidiecezji była parafia Borzyszków k/Bytowa. Od miasta Białoborga na Pomorzu linię graniczna między archidiecezją a biskupstwem poznańskim stanowiła rzeka Głód aż do Noteci pod

44 Por. Kor y tk ow s k i J., op. cit., t. I, s. 34.

45 Now a cki J., op. cit., s. 36 .

${ }^{46} \mathrm{D} \nmid \mathrm{u} \mathrm{g}$ os z J., Catalogus archiepiscoporum Gnesnensium, W: Opera omnia. Ed. I. Polkowski, Z. Pauli, Kraków 1887, t. I, s. 361; Tenże, Catalogus episcoporum Cracoviensium, W: Tamże, s. 415; Tenże, Liber beneficiorum dioecesis Cracoviensis. Ed. A. Przeździecki, Kraków1864, t. III, s. 165; E a sk i J., Liber beneficiorum archidioecesis Gnesnensis. Ed. J. E u k ow ski, Gniezno 1881, t. II, s. 117 n.; K u m or B., Granice (Archi)diecezji krakowskiej (1000-1939), „Prawo kanoniczne”, VI (1963), z. $1-4$ s. 543.

${ }_{47}$ 玉 a ski J., op. cit., t. I (1889), t. II (1881); Korytkowski J., Mapa archidiecezji gnieźnieńskiej jaka była $w$ XVI w., W: J. Łaski, op. cit., t. II (przy końcu); W a ręz a k J., Mopa uposażenia ziemskiego arcybiskupstwa gnieźnieńskiego $w$ wiekuch srednich, W: Tenże, op. cit., (przy końcu książki). 
Miasteczkiem, a stąd biegła na południe do Pobiedzisk, pozostawiając Gołańcze, Węgrowiec i Kiszkowo po stronie Gniezna. Od Pobiedzisk granica zachodnia zwężała się na niekorzyść archidiecezji ku południowi aż do rzeki Lutyni, pozostawiając Wrześnię po stronie archidiecezji. Od Lutyni poprzez Grabów, Wieruszów i Bolesławice i dalej Prosną biegła granica aż do Krzepic, gdzie rozpoczynało się sąsiedztwo $z$ diecezją krakowską. Ostrzeszów, Kępno i Byczyna pozostawały po stronie wrocławskiej. Od Krzepic granica biegła w kierunku południowo-wschodnim aż do źródeł Nidy i Chęcin w rejonie Kielc. Od Chęcin linia graniczna szła w kierunku zachodnim korytem rzeki Pilicy aż do Nowego Miasta, a następnie w kierunku północnym aż do parafii Kocierzów, Gembice i Kwieciszewo. Od Kwieciszewa na Kujawach linia graniczna biegła na północ i korytem Noteci aż do Nakła, a stąd w kierunku aż do Borzyszkowa k/Bytowa. Do archidiecezji należała nadto enklawa na pograniczu diecezji poznańskiej i wrocławskiej $z$ parafiami: Kobylin, Krotoszyn i Zduny.

\section{d) Ostatnie zmiany graniczne przed $1772 \mathrm{r}$.}

Ostatnie zmiany geograficzne archidiecezji przed rozbiorami Polski nastąpiły w latach 60-tych XVIII w. Biskupstwo włocławskie jeszcze od czasów średniowiecznych posiadało bogate uposażenie $\mathrm{m}$. in. na terenie archidiecezji gnieźnieńskiej, położona $w$ rejonie Piotrkowa $w$ granicach dawnego województwa sieradzkiego. Były to klucze gospodarcze: wolbromski, smardzewicki, grabicki, czarnociński, łaznowski i niesułowski o łącznej ilości 2 miasta (Wolborz, Łódź), oraz 51 wsi (w ro$\mathrm{ku} 1582)^{48}$. W Wolborzu też, gdzie znajdował się okazały pałac biskupi, najczęściej rezydowali biskupi włocławscy, zwłaszcza w XVIII w., chociaż było to wbrew prawu kościelnemu, które nakazywało biskupom rezydencję na terenie własnej diecezji. $\mathrm{Z}$ tego też względu w r. 1761 bp. włocławski A. S. Dembowski zwrócił się do prymasa Wladysława Łubieńskiego z propozycją zamiany parafii, leżących w kluczach gospodarczych wolborskim, smardzewickim i grabickim, przynależnych pod względem kościelnym do archidiecezji gnieźnieńskiej, w zamian za parafie diecezji włocławskiej $\mathrm{m}$. in. w rejonie Bydgoszczy, na co otrzymał w zasadzie zgodę prymasa. 12 IV $1761 \mathrm{r}$. podobną prośbę skierował pod adres kapituły metropolitalnej w Gnieźnie, a 12

$48 \dot{Z}$ y tk o w icz L., Inwentarz dóbr stolowych biskupstwa wloclawskiego $w$ r. 1582, Toruń 195̣3, s. $82 \mathrm{n}$. 
VIII t.r. - do kapituły we Włocławku ${ }^{49}$. Tymczasem mimo zgody prymasa i kapituły włocławskiej kapituła metropolitalna na posiedzeniu 30 IV 1762 w Gnieźnie podzieliła się. Część kapituły wypowiedziała się przeciwko planowanej zmianie, twierdząc, że już w r. 1761 odrzucono plan zamiany i nie ma $z$ niej żadnego pożytku dla archidiecezji. Co więcej ze zmiany wynikają pewne szkody, w zamian za kolegiatę diecezjalną archidiecezja ma otrzymać szereg kościołów w stanie opłakanym, zaś za duchowieństwo diecezjalne przejdą pod jurysdykcję arcybiskupa zakonnicy (wyjęci) i liczni akatolicy. Wreszcie jako ostatni motyw swego negatywnego stanowiska kapituła wysunęla zarzut, że nie powołano w tym celu specjalnej komisji, a głosowanie nad konsensem odbywało się publicznie, a nie tajnie ${ }^{50}$. Pozostała część kapituły na tymże posiedzeniu (30 IV 1762) wyraziła potrzebną zgodę, utrzymując, że sprawy zamiany były wprawdzie rozważane w $1761 \mathrm{r}$., ale nie jest prawdą jakoby kapituła je odrzuciła. Zgodę, czy jej brak może rozstrzygnąć tylko Stolica Apostolska. Odnośnie zaś głosowania stwierdzono, że tajne głosowanie potrzebne jest tylko przy wyborach ${ }^{51}$.

W takiej sytuacji zwrócil się biskup włocławski A.K. Ostrowski (następca Dembowskiego) listem z dnia 23 VI 1762 do kardynała protektora Polski, by poparł sprawę zamiany $u$ papieża Klemensa XIII ${ }^{52}$. Prawdopodobnie do Stolicy Apostolskiej zwróciła się również gnieźnieńska kapituła metropolitalna, co niedwuznacznie wynika z listu bpa A. K. Ostrowskiego do papieża i prawdopodobnie $z$ tego powodu dopiero 3 VIII 1764 r. dekretem Kongregacji konsystorialnej Cum R. P. D. Vladislaus Lubieński pap. Klemens XIII nadał ostatecznie zamianie sankcję kanoniczną ${ }^{53}$. W myśl tego dekretu archidiecezja straciła na rzecz Włocławka 1 kolegiate $\mathrm{w}$ Wolborzu (5 prałatur i 4 kanonie) wraz $z$ parafią, a nadto 7 dalszych parafii:

40 Koceniak J., Antoni Sebastian Dembowski biskup włocławski $i$ pomorski. Sylwetka z czasów saskich, Warszawa 1953, s. $262 \mathrm{n}$.

50 ADWłoc. (Archiwum Diecezjalne we Włocławku) 53 (52) 1758-62 Demb. II. Acta dioecesana sub episcopatu E. D. Antoni Sebast. Dembowski 1758-1762, vol. II, k. 210-210'.

${ }^{51}$ Tamże, k. $210^{\prime}-211^{\prime}$.

52 Tamże, k. 209.

53 ADWłoc. 58/57 763-69 Ostr. I. Acta curiae episcopalis A. C. Ostrowski episcopi Vladislaviensis et Pomeraniae 1763/69, vol. I, s. 74-76; Documenta ecclesias civitatis Bidgostiensis (Bromberg) concernentia, (Bydgoszcz) 1918, s. 148-149; por. Regesty wybranych zapisek $z$ akt dziaZalności arcybiskupów gnieźnieńskich. Wyd. H. Rybus, „Archiwa, Biblioteki i Muzea Kościelne”, III(1961), z. 1/2, s. 374. 
Czarnocin, Chorzęcin, Łazanów, Łódź, Gałków, Nagorzyce i Niesułków wraz z klasztorem franciszkańskim w Smarzowicach. Jako rekompesatę archidiecezja zyskała 12 parafii, Trzy miasta Bydgoszcz wraz z kolegium jezuitów i konwentami klarysek i bernardynów, Gębice i Barcin, a nadto parafie wiejskie: Strzelów, Dąbrówka, Ostrów k/Kościelca, Ludzisko, Skulsk, Wawrzynowo, Broniszewo, Brdów i Modzerowo przynależne uprzednio do dekanatów bydgoskiego, inowrocławskiego, kruszwickiego i izbickiego w diecezji wlocławskiej ${ }^{54}$. Dekretem Quod cum pro parte z dnia $9 \mathrm{~V} 1765 \mathrm{r}$. nuncjusz warszawski, arcybiskup Eugeniusz Visconti jako delegat apostolski wprowadził w życie zarządzenie papieskie, które ogłosił 6 IX 1765 r. w kolegiacie wolborskiej wobec biskupa włocławskiego A. K. Ostrowskiego ${ }^{55}$.

\section{2. „Rozbiory” archidiecezji i formowanie nowego jej terytorium}

a) Geneza zmian terytorialnych i zmiana granic $w$ latach $1772-1815$.

Podczas gdy dotychczasowe zmiany terytorialne archidiecezji posiadały charakter wyrównywania jej granic (poza sporadycznymi wyjątkami), to wszystkie zmiany w latach 1772-1821 nosiły na sobie wyraźne piętno polityczne i były następstwem takich procesów politycznych jak rozbiory Polski (1772/1795), utworzenie i powiększenie Księstwa Warszawskiego (1807/09) i powołanie do życia Królestwa Polskiego (1815). Ponieważ w latach 1772-1815 tereny archidiecezji gnieźnieńskiej zmieniały kilka razy przynależność państwową (Polska, Prusy, Austria, Rosja), stąd i ich przynależność pod względem kościelnym ulegała różnym kolejom. Mocarstwa rozbiorowe w odniesieniu do zagarniętych ziem polskich przestrzegały zasady, że biskup „zagraniczny” nie może spełniać jurysdykcji kościelnej nad wiernymi innego zaboru. W konsekwencji więc tworzono we wszystkich trzech zaborach najpierw oficjalaty ge-

\footnotetext{
54 Jak wyżej; por. Chodyński St., Zmiana kościolów w $r .1765$, „Kronika diecezji kujawsko-kaliskiej”, VII(1913), $\mathrm{nr} 5 \mathrm{~s}$. 148-50; S ub e r a I., Terytorium diecezji wtocławskiej $i$ pomorskiej, „Prawo Kanoniczne", IV(1961), nr 1/4, s. $688 \mathrm{n}$.

${ }_{55}$ ADWłoc. 58/57 1763/69 Ostr. I. Acta curiae, s. 70-73; Documenta ecclesias civitatis Bidgostiensis concernentia, s. $147 / 52$; por. L i b r o wski St., Wizytacje diecezji włocławskiej. Cz. 1. Wizytacje diecezji kujawskiej i pomorskiej. T. 1. Opracowanie archiwalno źródłoznawcze, „Archiwa, Biblioteki i Muzea Kościelne", VIII (1964), s. 33 n.
} 
neralne dla tych terenów archidiecezji, które były oddzielone kordonem granicznym od Gniezna. Była to najczęściej przejściowa forma administracji kościelnej. Zwykle po tym następowało przydzielenie „zakordonowych” części archidiecezji do sąsiednich diecezji, lub też inkorporacja do diecezji nowokreowanych.

Rozbiory Polski (1772/95) przyniosły w konsekwencji podział archidiecezji gnieźnieńskiej początkowo między Prusy i Austrię, a następnie i Rosję. Tuż po pierwszym rozbiorze Polski rząd pruski zamierzał dla zagarniętej części archidiecezji, obejmującej archidiakonat kamieński i okręg nadnotecki, zamianować osobnego administratora niezależnego od Gniezna i wynieść go do godności biskupa in partibus ${ }^{56}$. Wprawdzie projektu tego nie zrealizowano, nie mniej pod naciskiem rządu pruskiego jedność kościelna terenów odciętych zaborczym kordonem pruskim została mocno rozluźniona. Jeszcze prymas A. K. Ostrowski 1 VII $1780 \mathrm{r}$. przeprowadził zmiany w organizacji kościelnej archidiecezji ze względu na nową granicę polityczną państwa, przydzielając parafie i dekanaty pozostałe po r. 1772 po polskiej stronie do dekanatów i archidiakonatów w Polsce (m. in. utworzył wówczas dekanat rogowski ${ }^{57}$ ). Tenże arcybiskup prawdopodobnie 1 VII $1780 \mathrm{r}$. był zmuszony utworzyć oficjalat generalny dla „pruskiej” części archidiecezji $\mathrm{w}$ Kamieniu, powierzając jurysdykcje kościelną na terenie nowoutworzonego oficjalatu ks. Antoniemu Sikorskiemu, archiadiakonowi kamieńskiemu ${ }^{58}$. Po śmierci prymasa A. K. Ostrowskiego nowy arcybiskup M. J. Poniatowski zatwierdzil 19 III 1785 r. ,kamieńskiego" oficjała generalnego, powierzając mu jurysdykcję własną i delegowaną ${ }^{59}$, a kiedy w r. 1788 ks. A. Sikorski z powodu podeszłego wieku zrezygnował z urzędu, wyznaczył na jego miejsce 16 VI 1788 r. ks. Wojciecha Szeinerta, proboszcza w Smogulcu i kanonika honorowego poznańskiego (in archidiaconatu Camenesi atque in tota ditione Borussorum) ${ }^{60}$. Tegoż dnia utworzył prymas drugą instancję

56 M i ask ow ski K., Fryderyk II a Kościól katolicki w zabranych Polsce dzielnicach, „Przegląd powszechny”, 165(1925)81.

57 AAGniez. (Archiwum Archidiecezjalne w Gnieźnie) D. 1. Acta postcurialia R. D. M. G. Ciolek Poniatowski archiepiscopi Gnesn. 1785/86, s. 392; por. Regesty wybranych zapisek, s. 278.

*58 Tamże, s. 96.

${ }^{50}$ Tamże, s. 96-97.

60 AAGniez. D. 2. Acta... M. G. Poniatowski 1787-1788, s. 391-93, 393-399 (Facultates Romanae); Tamże, D. 3. Acta. M. G. Poniatowski 1789-1790, s. 368-369 (27 IV 1790 Communicatio facultatum); Tamże, D. 4. Acta ... M. G. Poniatowski $1793-1794$, s. 144 n. (12 IX 1793 Communicatio facultatum). 
apelacyjną dla „pruskiej” części archidiecezji, zlecając jej kierownictwo ks. A. Sikorskiemu ${ }^{61}$.

Stan taki utrzymał się nawet po drugim i trzecim rozbiorze Polski, chociaż samo Gniezno znalazło się w granicach zaboru pruskiego. 12 III i 10 VII 1796 r. nowy arcybiskup gnieźnieński, Ignacy Krasicki, zatwierdził na urzędzie oficjała generalnego ks. Szeinerta, przy czym władza jego, jak to mówił dekret arcybiskupa, rozciągała się na dekanaty: człuchowski, więcborski, tucholski, nakielski, łobziński, żniński i kcyński ${ }^{62}$. A kiedy ks. Szeinert zrezygnował $z$ urzędu z powodu choroby, wówczas 2 X 1798 r. takie uprawnienia delegował ks. Antoniemu Tuszyńskiemu ${ }^{63}$. Dopiero arcybiskup Ignacy Raczyński zniósł oficjalat generalny 23 II 1808 r., a w jego miejsce przywrócił oficjalat okręgowy; jurysdykcję otrzymał tym razem ks. Xawery Trzebiatowski, proboszcz w Więcborku ${ }^{64}$.

Nowe trudności $w$ administracji kościelnej tej części archidiecezji wyłoniły się znów w związku z powstaniem Księstwa Warszawskiego. 17 IV 1811 r. arcybiskup Ignacy Raczyński wyłączył dekanaty żniński i kcyński z oficjalatu kamieńskiego, pozostalego w granicach Prus i przyłączył je do archidiakonatu gnieźnieńskiego i oficjalatu generalnego w Gnieźnie, które zostało objęte granicami Księstwa Warszawskiego ${ }^{65}$. Niebawem ze względu na żądanie Berlina doszło do przywrócenia stanu administracji archidiecezji $z$ lat po pierwszym rozbiorze. $24 \mathrm{~V} 1814 \mathrm{r}$. arcybiskup Raczyński przywrócił generalny oficjalat w Kamieniu ,dla tej części archidiakonatu kamieńskiego, która znajduje się w granicach Prus", powierzając odpowiednią władzę kościelną $w$ oficjalacie ks. Wawrzyńcowi Kłossowskiemu ${ }^{66}$. Tym razem taki stan administracji kościelnej utrzymał się do r. 1821.

Pierwsze cięcia całości terytorium archidiecezji przyszły pod zaborem austriackim. W trzecim bowiem rozbiorze Polski Austria zajęła część archidiecezji na południe od rzeki Pilicy. Wprawdzie jeszcze w latach 1796/98 arcybiskup Ignacy Kra-

61 Tamże, D. 2. Acta, s. $399-400$.

62 Tamże, D. 6. Acta postcurialia Cels. R. D. Ignatii Krasicki archiepiscopi Gnesn. ex an. 1795-1799, s. 15-17 (12 III 1796), 79-81 (10 VII 1796).

${ }_{63}$ Tamże, s. 255-259.

64 AAGniez. D. 7. Acta postcurialia Cels. R. D. Ignatii Raczyński principis archiepiscopi Gnezn. ex an. 1807-1811, s. 77, $155 \mathrm{n}$.

${ }_{65}$ Tamże (pod datą 17 IV 1811).

66 AAGniez. D. 8. Acta... Ignatii Raczyński... 1811-1815, s. 438-439. 
sicki rządził bezpośrednio w ,austriackiej” części archidiecezji, $\mathrm{m}$. in. erygując kaplicę publiczną $\mathrm{w}$ Rączkach k/Przedborza (13 II 1796) i porządkując sprawy fundacyjne parafii Dąbrowa k/Opoczna (9 V 1797) ${ }^{67}$, ale nie trwało to zbyt długo. $\mathrm{Na}$ żądanie zaborczego dworu wiedeńskiego dnia $8 \mathrm{~V} 1798 \mathrm{r}$. utworzył Krasicki dla ,austriackiej” części archidiecezji oficjalat generalny $w$ Kurzelowie, poddając jego jurysdykcji sześć dekanatów (kurzelowski, małogoski, opoczyński, przytycki, skrzyński i żarnowski) z 84 parafiami. Oficjałem został ks. Franciszek Zdziechowicz, kanonik kurzelewski i prepozyt w Piekoszowie. Równocześnie zniósł Krasicki dwa oficjalaty okręgowe w Kurzelewie i Skrzyńsku ${ }^{63}$. Na skutek starań Wiednia ta część archidiecezji została poddana przed r. 1799 jurysdykcji ordynariusza krakowskiego ${ }^{69}$. W r. 1800 ordynariusz krakowski przyjmował sprawozdania z zarządu oficjalatem od generalnego oficjała kurzelowskiego ${ }^{70} .27$ XII 1800 r. konsystorz krakowski przejął $\mathrm{z}$ rąk gubernium austriackiego oryginalne dokumenty dotyczące oficjalatu kurzelowskiego, wydane prawdopodobnie przez Gniezno na żądanie władz austriackich ${ }^{71}$. Krakowskie prowizorium administracyjne na tym terenie zostało niebawem uprawomocnione przez nuncjaturę wiedeńską, a następnie potwierdzone przez pap. Piusa VII 27 VI $1801 \mathrm{r}$. Władze austriackie przesłały odnośne dokumenty jurysdykcyjne administratorowi diecezji krakowskiej, ks. Józefowi Olechowskiemu "2. Administracji „krakowskiej" oficjalatu kurzelewskiego położył kres pap. Pius VII, kiedy w porozumieniu $z$ ces. Franciszkiem I utworzył diecezję kielecką i bullą

67 Regesty wybranych zapisek, s. 400, 402. Dla całości zmian w granicach archidiecezji na tym odcinku zob. K u m or B., Organizacja terytorialna diecezji kieleckiej. „Nasza Przeszlaść” 17 (1963) s. $187 \mathrm{nn}$.

68 AAGniez. D. 6. Acta... Ign. Krasicki 1795-1799 (pod data 8 V 1798); AAPoz. (Archiwum Archidiecezjalne w Poznaniu) OA 2087 Acta corespondentiae cum S. Sede Apostolica ejusque officialibus, k. 144 (wymienia 6 dekanatów i 86 parafii).

${ }_{69} \mathrm{P}$ e c k o w s k i J., Józef Olechowski archidiakon $i$ sufragan krakowski 1735-1806, Kraków 1926, s. 172, 177.

70 AKMK (Archiwum Kurii Metropolitalnej w Krakowie) Acta episcopalia, vol. 122 (1797-1800), k. 206 (Resignatio custodiae Cureloviensis); Prothocollum actorum exhibitorum 1800, nr 652 (11 XII 1800); Prothocollum exhibitorum anni 1801, nr 366.

71 AKMK Prothocollum 1800, nr 697.

72 AKMK Prothocollum exhibitorum anni 1801, nr 467. Praesidium mandat facultates Illustr. Domino administratori super territorio archidioecesis Gnesnensis in Galicia Occidentali sito, ab Eminen. Cardinali et Nuntio Apostolico Viennensi Ruffo prorogatas a Ssmo Patre Pio Papa VII nunc confirmatas, actis ingrossari. 
erekcyjną Indefessum personarum regia dignitate fulgentium z 9 VI $1805 \mathrm{r}$. włączył go do nowokreowanej diecezji kieleckiej ${ }^{73}$. Ze względu na liczne wojny napoleońskie bulla papieska nie została początkowo wprowadzona w życie. Dopiero na żądanie nadwornej kancelarii wiedeńskiej metropolita lwowski, Kajetan Kicki, jako delegat apostolski zwrócił się przed 6 VI 1807 r. do arcybiskupa i kapituły gnieźnieńskiej o zgodę na dysmembrację diecezji. Po uprzedniej konsultacji.z pruską kamerą poznańską arcybiskup i kapituła metropolitalna wyrazili potrzebną zgodę 30 VII $1807 \mathrm{r}$. ${ }^{74}$. Teraz też nastąpiła egzekucja bulli papieskiej (17 IX 1807) na podstawie dekretu delegata apostolskiego Quae a Sanctissimo Domino nostro ${ }^{7:}$.

Trzeba zaznaczyć, że separacja archidiakonatu kurzelowskiego do nowoutworzonej diecezji kieleckiej była tylko jednym z punktów ogólnej regulacji metropolii i diecezji, jaka miała miejsce $\mathrm{w}$ monarchii habsburskiej łącznie $\mathrm{z}$ ziemiami pierwszego i trzeciego zaboru. Wówczas to m. in. zniesiono diecezję tarnowską (1805/07), a jej terytorium podzielono między diecezję przemyską i krakowską ${ }^{70}$, oraz diecezję chełmska, a w jej miejsce utworzono diecezję lubelską, a nadto z części diecezji krakowskiej i archidiecezji gnieźnieńskiej erygowano nowe biskupstwo w Kielcach ${ }^{77}$.

Po nowych zmianach politycznych i ukonstytuowaniu siez Księstwa Warszawskiego prefekt departamentu kaliskiego zwrócił się 11 X $1811 \mathrm{r}$. do arcybiskupa gnieźnieńskiego, aby ten $\mathrm{w}$ porozumieniu $\mathrm{z}$ biskupem kieleckim i Stolicą Apostolską wyłączył opactwo cysterskie w Sulejowie z diecezji kieleckiej i przywrócił je archidiecezji gnieźnieńskiej. W odpowiedzi na to arcybiskup Raczyński doniósł 5 XI 1811 r., ,że myślą jest rządu wyprosić u Stolicy Apostolskiej nowy diecezjów podział..., to gdy to nastąpi tym samym przypadek Sulejowa ułatwiony zostanie" 78 . Tym samym zwrot nawet cząstki tere-' nów utraconych na tym odcinku nie nastąpił nigdy.

${ }^{73}$ BRC (Bullarii Romani Continuatio), t. XII, s. 307-319.

74 AAGniez. B. 40. Acta capituli metropolitani Gnesnensis, vol. 41 (1799-1811), k. 263 n., 207 n.

75 ADKiel. (Archiwum Diecezjalne w Kielcach) Acta capituli cathedralis Tarnoviensis, s. 299-301.

i6 $\mathrm{K}$ umor B., Dzieje polityczno-geograficzne diecezji tarnowskiej, s. $63 \mathrm{n}$.

${ }_{77} \mathrm{~K}$ u m or B., Organizacja terytorialna diecezji kieleckiej, s. $187 \mathrm{nn}$.

78 AAPozn. Akta arcybiskupie. Korespondencja za świeckimi urzędami i osobami, vol. I (1808-1815), k. 85. 
b) Uformowanie nowego terytorium archidiecez $j i$ i jej granice w latach 1815-1821.

Daleko większe zmiany na tym polu przyniosło utworzenie Królestwa Polskiego na kongresie wiedeńskim w r. 1815. Po nowym wytyczeniu granic politycznych 398 parafii $z$ archidiecezji znalazło się w granicach Królestwa Polskiego, a tylko 222 pozostały na terenie Wielkiego Księstwa Poznańskiego i 31 na Pomorzu 79. W r. 1815 arcybiskup Raczyński musiał się zrzec jurysdykcji w „polskiej” części archidiecezji. Dekretem z dnia 25 XI $1815 \mathrm{r}$, w myśl żądań cara Aleksandra I utworzył ,administrację generalną części archidiecezji gnieźnieńskiej, objętej nowymi granicami Królestwa Polskiego", powierzając w niej rządy ks. Andrzejowi Wołłowiczowi, archidiakonowi warszawskiemu ${ }^{80}$. 6 XII 1815 r. zniósł Raczyński generalny oficjalat łowicki, oraz konsystorze okręgowe w Uniejowie, Łęczycy, Wieluniu i Kaliszu, będące w granicach archidiecezji w Królestwie Polskim ${ }^{81}$, a w okólniku z dnia 8 XII t. r., zaadresowanym do wszystkich oficjałów okręgowych, dziekanów i proboszczów tej części archidiecezji powiadomil ich o zmianie jurysdykcji kościelnej ${ }^{82}$. 23 I 1816 r. Raczyński w liście osobistym do pap. Piusa VII powiadomił o zaszłych zmianach Stolice Apostolską ${ }^{83}$. Wprawdzie jeszcze 16 III 1818 r. pisał w liście do kapituły gnieźnieńskiej, że „,archidiecezja moja nawet co do części do Królestwa Polskiego odpadłej podług prawa kanonicznego pod jurysdykcją moją zostaje, którą przeze mnie ustanowiony delegat sprawuje" ${ }^{84}$, ale już 28 III t. r., pap. Pius ElII w liście apostolskim Justis gravibusque causis moti, skierowanym na ręce Raczyńskiego, postanowił nowe urządzenie hierarchii kościelnej w Królestwie, a tym samym dysmembracje ,polskiej" części archidiecezji ${ }^{85}$. 1 VI 1818 r. W odpowiedzi na powyższy list papieski Raczyński wyraził zgodę na podział archidiecezji ${ }^{86}$.

79 AAPozn. OA 2087 Acta correspondentiae, k. 227 (Raczyński do Piusa VII - 23 I 1816).

80 AAGniez. D. 8. Acta postcurialia... Ign. Raczyński archiep. Gnesn. 1811-1815, s. $764-766$.

81 Tamże, s. $766 \mathrm{n}$.

82 Tamże, s. 767.

83 AAGniez. D. 9. Acta postcurialia... Ign. Raczyński 1816/1818, s. 8-9.

${ }^{84}$ Tamże, Gr. 4 Ia, nr 30. Listy arcybiskupa Raczyńskiego do kapituły (bez paginacji).

${ }_{85}$ Tamże, B. 42. Acta capituli metropol. Gnesn. 1811-1824, k. $188 \mathrm{n}$.

86. AAGniez. Acta Raczyński... 1816/18, s. 112. 
Całość tego procesu zmierzała do uporządkowania hierarchii kościelnej w nowoutworzonym Królestwie Polskim. Jeszcze 12 III 1818 r. pap. Pius VII bullą Militantis Ecclesiae wyniósł Warszawę do godności metropolii i zapowiedział dalszą reorganizację Kościoła ${ }^{87}$. Nowe bowiem granice polityczne Królestwa spowodowały ogromne zamieszanie w strukturze organizacyjnej Kościoła. Niektóre diecezje, których stolice pozostawały w granicach Królestwa zostały zacieśnione przez nowy kordon graniczny do nie wielkiej części dawnego terytorium (Włocławek utracił całe Pomorze, Kraków zaś przedwiślańską część diecezji), podczas gdy inne posiadały stolice swoje poza obrębem Królestwa (Gniezno, Przemyśl), chociaż znaczna część ich terytorium znajdowała się w Królestwie. Taki stan rzeczy wymagał nowego podziału administracyjnego Kościoła. W związku też z tym na mocy bulli pap. Piusa VII $E x$ imposita nobis z 30 VI 1818 r. dokonano podziału zakordonowej części archidiecezji. Do archidiecezji warszawskiej wcielono 114 parafii z 2 kolegiatami (Łęczyca, Łowicz) w dekanatach łowickim, łęczyckim, brzezińskim, skierniewickim rawskim, kolskim i kutnowskim. Do diecezji włocławskiej czyli kaliskiej przypadło przeszło 290 parafii z 6 kolegiatami (Kalisz, Sieradz, Łask, Wieluń, Uniejów, Chocz) z dawnych archidiakonatów: kaliskiego, uniejowskiego, gnieźnieńskiego, łęczyckiego, lowickiego i terytorium wieluńskiego ${ }^{88}$.

Po tak znacznym okrojeniu archidiecezji rząd pruski projektował całkowicie znieść archidiecezję, a jej tereny wcielić do diecezji chełmińskiej, Wrocław zaś wynieść do godności metropolii. Był też projekt zacieśnienia archidiecezji do terenu samego miasta Gniezna. Energiczny jednakże sprzeciw arcybiskupa Gorzeńskiego i poparcie Stolicy Apostolskiej stanęły na przeszkodzie w realizacji tych planów ${ }^{89}$. 15 IX $1820 \mathrm{r}$. namiestnik króla pruskiego w Poznaniu, ks. Radziwiłł powiadomił kapitułę metropolitalną, że $\mathrm{w}$ odpowiedzi na prośbę kapituly $\mathrm{z}$ dnia 2 VIII $1820 \mathrm{r}$. król pruski najwyższym postanowieniem z dnia 30 VIII 1820 r. postanowił utrzymać nadal archidiecezję gnieźnieńską wraz $z$ kapitułą metropolitalną ${ }^{90}$.

87 Papiestwo wobec sprawy polskiej, s. $268 \mathrm{n}$.

88 Papiestwo wobec sprawy polskiej w latach 1772-1864. Wybór źródeł. Oprac. O. Beiersdirf, Wrocław 1960, s. 273-278; por. K or y t k o ws k i J., op. cit., t. I, s. 39.

${ }^{89}$ H o f man $\mathrm{n}$ B., Wykonanie bulli ,De salute animarum" $w$ Wielkim Księstwie Poznañskim, „Roczniki Historyczne”, VIII(1932) 28-55.

90 AAGniez. Acta capituli 1811, 1824, k. 237. 
Dalsze zmiany ustroju geografii kościelnej archidiecezji przyniosła bulla pap. Piusa VII De salute animarum z 16 VII 1821 r. ${ }^{91}$. Wspomnianą bullą papież „wyniósł Poznań do godności metropolii... a zarazem aeque principaliter na zawsze dołączył do arcybiskupiego kościoła gnieźnieńskiego św. Wojciecha i zjednoczył go z nim". Obydwa arcybiskupstwa były odtąd połączone unią personalna $w$ osobie jednego arcybiskupa, zachowując odtąd odrębne kapituły, seminarium i sufraganów, a w czasie wakansu wlasnego administratora i wikariusza kapitulnego ${ }^{92}$. Równocześnie papież odłączył od archidiecezji cały archidiakonat kamieński, leżący na Pomorzu z 3 dekanatami (człuchowskim, tucholskim i kamieńskim), 31 parafiami i 1 kolegiatą (Kamień) i wcielił do diecezji chełmińskiej ${ }^{93}$. Powiększył natomiast archidiecezję gnieźnieńską przez przyłączenie archidiakonatu kruszwickiego $\mathrm{z}$ diecezji włocławskiej z 3 dekanatami (inowrocławski, gniewkowski i kruszwicki), 38 parafiami i 1 kolegiatą (Kruszwica) ${ }^{94}$, które od 18 VII $1817 \mathrm{r}$. tworzyły ,administrację generalną", zarządzaną przez biskupa poznańskiego, Tymoteusza Gorzeńskiego ${ }^{95}$. Bulla papieska nie została jednakże należycie wykonana. Wbrew tenorowi bulli parafie Skarboszewo i Grabie przydzielone diecezji włocławskiej, pozostały nadal przy archidiecezji gnieźnieńskiej ${ }^{96}$.

W rezultacie omówionych zmian granicznych archidiecezja otrzymała nowe terytorium, w skład którego weszły tylko niektóre części dawnej archidiecezji wraz z niektórymi terenami dawnej diecezji włocławskiej. Trzeba też zaznaczyć, że proces formowania nowych granic archidiecezji w latach 1815/1821 był tylko częścią nowej organizacji Kościoła w Prusach po r. 1815. Po kongresie wiedeńskim Prusy otrzymały na zachodzie (Nadrenia) i na wschodzie (W. Księstwo Poznańskie) kraje z ludnością katolicką, a same były państwem o tradycjach pro-

91 Papiestwo wobec sprawy polskiej, s 286-304; Die neueste Einrichtung des kath. Kirchenwesens in den Königlichpreussischen Staaten, oder päpstliche bulle vom $16 \mathrm{Juli}$ 1821, Frankfurt a. M. 1822, s. 90-91.

92 Fi j ałek J., Biskupstwa rzymsko katolickie $w$ Rzeczypospolitej Polskiej, „Nova Polonia Sacra”, I(1928)337.

${ }^{93}$ Elenchus cleri archidioecesis Gnesnensis, Poznań 1815, s. 120 wymienia $\mathrm{w}$ archidiakonacie kamieńskim 5 dekanatów i 54 parafie.

94 Elenchus archidioec. Gnesnensis, Poznań 1824, s. 90-93 wymienia 3 dekanaty i 39 parafii; Elenchus dioec. Cujaviensis et Pomeraniae, Warszawa 1815 , s. $82-87$ podaje 38 parafii.

${ }^{95}$ ADWłoc. 77(377) 1815-1819 Malcz. Acta curialia... Franc. Skarbek Malczewski ep. Vlad. et Pomer. 1815-1819, s. 132-134.

${ }_{96} \mathrm{~J}$ u n g K., Katedra włocławska, Wlocławek 900, s. 72. 
testanckich i kierowały się w stosunku do Kościoła zasadą supremacji państwowej. Stąd Stolica Apostolska dążyła do zawarcia z Prusami układu, rezultatem czego była bulla papieska De salute animarum (1821), tworząca w Prusach dwie prowincje kościelne: kolońską dla Nadrenii i gnieźnieńsko-poznańską dla Poznańskiego.

\section{Zmiany granic archidiecezji w latach 1918-1939}

a) Plany i zmiany granic archidiecezji $w$ latach 1918-1939

Ostatnie poważniejsze zmiany $\mathrm{w}$ granicach archidiecezji nastapiły w rezultacie pierwszej wojny światowej i powstania odrodzonego Państwa Polskiego. W związku z reorganizacją struktury hierarchicznej Kościoła łacińskiego w Polsce planowano na konferencji episkopatu metropolii warszawskiej, odbytej 18 i 19 III 1924 w Warszawie, wydzielić z archidiecezji gnieźnieńskiej powiat pleszewski na rzecz projektowanej diecezji kaliskiej, oraz Kujawy wraz z Kruszwica, Inowrocławiem i Bydgoszczą celem powiększenia diecezji włocławskiej. W zamian za te straty proponowano powiększenie archidiecezji przez przyłączenie powiatu słupeckiego $z$ diecezji włocławskiej ${ }^{97}$. Plany te jednakże zostały odrzucone przez kard. E. Dalbora arcybiskupa gnieźnieńskiego i poznańskiego, a $\mathrm{w}$ ich miejsce opracowano nowe, które przewidywały tylko nieznaczne przesunięcia graniczne $\mathrm{w}$ stanie posiadania archidiecezji. Ten też projekt wszedł do bulli pap. Piusa XI Vixdum Poloniae unitas z $28 \times 1925$ r., mocą której odłączono od Gniezna na rzecz archidiecezji poznańskiej 2 dekanaty ołobocki i krotoszyński z 22 parafiami i filiami, 60722 wiernymi i 28 kapłanami. W drodze rekompensaty przyłączono do Gniezna $z$ archidiecezji poznańskiej 2 dekanaty jarociński i miłosławski z 28 parafiami, 1 filią (Nowa Wieś), 45160 wiernymi i 22 kapłanami ${ }^{98}$. Tym samym uległa likwidacji istniejąca od XII wieku enklawa jurysdykcyjna Gniezna w rejonie Krotoszyna i Zdun, oddzielona od obszaru archidiecezji gnieźnieńskiej posiadłościami archidiecezji poznańskiej.

${ }_{97}$ ADWłoc. Korespondencja ze Stolica Apostolska (Maszynopis bez paginacji).

${ }_{98} \mathrm{~W}$ i śli cki J., Konkordat. Studium prawne, Lublin 1926, s. 173 n.; Czernicki Z. A., Schematyzm Kościola rzymsko katolickiego $w$ Rzeczypospolitej Polskiej, Kraków 1925, s. 11-19, 23-33. 
Ostatnie przed $1939 \mathrm{r}$. nieznaczne przesunięcia granicy miały miejsce 28 I 1939 r., kiedy to pap. Pius XI na mocy dekretu Kongregacji konsystorialnej Fideles pagi odłączył wieś Sanniki od archidiecezji gnieźnieńskiej i przydzielił ją do parafii Iwno w archidiecezji poznańskiej ${ }^{99}$.

\section{b) Statystyka}

Podane niżej dane statystyczne posiadają charakter przekrojowy a nie rozwojowy, ale są powiązane jak najbardziej $z$ dziejami archidiecezji, a zwłaszcza $z$ jej granicami.

$\mathrm{Na}$ początku XVI w. archidiecezja dzieliła się na 7 archidiakonatów (gnieźnieński, kaliski, kurzelowski, uniejowski, łęczycki, łowicki i kamieński). 1 Territorium Vielunense ad instar archidiaconatus, 41 dekanatów i 673 parafie. Nadto w pierwszej połowie XVI w. liczyła 11 kolegiat z kapitułami (Gniezno, Łask, Łęczyca, Uniejów, Kurzelów, Kalisz p. w. św. Pawła, Wieluń, Łowicz, Sieradz, Kamień i Wolborz) ${ }^{100}$.

Według relacji arcybiskupa Wojciecha Baranowskiego z 1612 r. kapituła katedralna obejmowała 7 prałatur i 24 kanonikaty gremialne, zaś archidiecezja - 8 archidiakonatów, 813 parafii, 6 opactw, 12 prepozytur zakonnych, 17 klasztorów męskich, 4 żeńskie i 2 seminaria duchowne ${ }^{101}$. W r. 1644 archidiecezja dzieliła się na 7 archidiakonatów, teryrorium wieluńskie, 43 dekanaty, 804 parafii (24 wakujące, 24 sprofanowane). W r. 1621 było 6 opactw, 16 klasztorów męskich 4 klasztory żeńskie, 2 kolegia jezuickie, oraz 11 kolegiat 102. $\mathrm{Na}$ synodzie archidiecezjalnym 7 VI 1720 archidiecezja dzieliła się na 7 archidiakonatów, 1 terytorium wieluńskie, 40 dekanatów, ok. 800 parafii, 12 kolegiat (przybyła kolegiata w Choczu), 6 opactw i 10 prepozytur ${ }^{103}$. W r. 1787 archidiecezja obejmowała: 7 archidiakonatów, 1 terytorium wieluńskie, 41 dekanatów, 808 parafii, w tym $666 \mathrm{w}$ Polsce, a $142 \mathrm{w}$ zaborze pruskim, 52 kościoły szpitalne ( $2 \mathrm{w}$ zaborze pruskim), 104 kaplice pu-

99 AAS XXXI(1939) $262 \mathrm{n}$.

${ }^{100}$ LBEask. I, s. 1-714; II, s. 1-506; por. J. Korytkowski, op. cit., t. I, 36-38.

101 Archiwum Kongregacji Soboru. Relacje biskupów. Archidiecezja gnieźnieńska 1612.

102 B oratyńs i L., Najdawniejsze relacje biskupów polskich o stanie diecezji (relationes status ecclesiarum), Kraków 1916, s. 8, 14.

${ }^{103}$ Constitutiones synodi archidioecesis Gnesnensis sub Stanislao Szembek archiepiscopo Gnesnensi a. D. 1720 celebratae, Warszawa 1720 k. $64-75^{\prime}$ Ordo et numerus ecclesiarum archidioecesis Gnesnensis. 
bliczne ( $17 \mathrm{w}$ zaborze pruskim), 14 opactw i prepozytur, 63 dalsze klasztory męskie, 13 żeńskich, 2 seminaria duchowne. W całej archidiecezji było 141 miast i miasteczek, 4690 wsi, 451159 osób sposobnych do sakramentów św., 62044 dzieci, 25551 protestantów, 23721 żydów, w całości 562481 osób.

W archidiecezji pracowało 1031 kaplanów diecezjalnych, 697 zakonnych, 186 braci zakonnych i 161 zakonnic ${ }^{104}$.

Po rozgraniczeniu w r. 1821 archidiecezja obejmowała 16 dekanatów, 216 parafii i 2 kolegiaty (Gniezno, Kruszwica) ${ }^{105}$. W r. 1911 archidiecezja liczyła 17 dekanatów, 208 parafii, 29 filii, 58 kaplic publicznych, 273 kapłanów, 113 zakonnice, 442765 wiernych i 2 kolegiaty ${ }^{106}$. W r. 1938 archidiecezja obejmowała 21 dekanatów, 261 parafii, 24 filii, 2 kolegiaty, 99 kaplic publicznych, 10 domów zakonnych męskich, 66 żeńskich, 381 kapłanów diecezjalnych, 44 zakonnych i 659229 wiernych ${ }^{107}$.

R es umé

Le diocèse archiépiscopal de Gniezno érigé en 1000 par le pape Sylvestre II par son territoire était un des plus grands diocèses de Pologne. Ses frontières les plus anciennes ne sont pas connues à cause de l'absence des données historiques. La plus ancienne source informant occasionnellement des frontières du diocèse est la bulle de protection du pape Innocent II Ex commisso nobis du 7 juillet 1136. D'après cette bulle le diocèse comprenait 16 châtellenies et environ 40 mille kilomètres carrés d'étendue. Etablies définitivement au XIIIe siècle les frontieres du diocèse ne subirent plus de changements notables jusqu' à l'année 1772. Ainsi, dans les année 1236-1309 fut réuni au diocèse l'archiđiaconé de Słupsk en Pcméranie Occidentale, mais qui, par suite de changements politiques, survenus dans cette region, fut rattaché de nouveau au diocèse de Kamień. Sur la frontière voisinante avec le diocèse de Poznań des changements insignifiants ont eu lieu aux XIVe et $X V$ siècles; depuis lors la frontière de ce côté fut stable jusqu'en 1772. Sur le segment de la frontière voisinant avec le diocèse de Wlocławek des changements plus notables n'ont eu lieu qu'en 1764, quand le diocèse a reçu 12 paroisses avec la ville de Bydgoszcz, échangés contre la région de Wolbórz ( 8 paroisses) cédée au diocèse de Wlocławek.

Les changements qu'avait subis le diocèse dans les années 1772-1821 ont été amenés les plus souvent par des causes politiques, liées avec.

104 Archiwum Kongregacji Soboru. Relacje biskupów. Archidiecezja gnieźnieńska 1789 (Relacja abpa M. J. Poniatowskiego); por. J. Korytkowski, Arcybiskupi, t. V. s. 199.

105 Elenchus cleri archidioecesis Gnesnensis, Poznań 1824, s. 77-_93.

106 Elenchus omnium ecclesiarum archidioecesis Gnesnensis a. D. 1911, Gniezno 1910 , s. 64 .

${ }_{107}$ Rocznik Archidiecezji Gnieźnieńskiej i Poznańskiej, Poznań 1938. s. 17,431 . 
les partages de la Pologne et la période qui les a suivis. Ainsi, le 9 juin 1805 le pape Pie VII par la bulle Indefessum personarum a détaché du diocèse tout l'archidiaconé de Kurzelów (6 décanats et 84 paroisses) et l'a réuni au diocèse de Kielce récemment érigé. Le même pape par la bulle Ex imposita nobis a Deo du 30 juin 1818 a detaché du diocèse 114 paroisses et les a reunies au diocèse archiépiscopal de Warszawa, et a 290 autres paroisses rattaché au diocèse de Włocławek ou de Kalisz. Toutes ces paroisses ont fait partie du territoire de la Pologne échue à la Russie. Après des tentatives sans resultat de la suppression du diocèse par le guovernernent prussien, son territoire a été formé à nouveau. Le pape Pie VII par la bulle De salute animarum a réuni le diocèse au diocèse archièpiscopal de Poznań par une union personnelle. En même temps il a detache du diocèse 31 paroisses de la Pomeranie (l'archidiaconé de Kamień) et les a réunies au diocèse de Wloclawek en détachant de lui 39 paroisses pour les attacher eu diocèse de Gniezno (l'archidiaconé de Kruszwica). En 1925 le pape Pie XI par la bulle Vixdum Poloniae unitas a détache du diocèse 2 décanats avec 22 paroisses pour les réunir au diocèse de Poznań; en revanche le diocèse de Gniezno a reçu 2 décanats avec 28 paroisses détachées du diocèse de Poznań. 


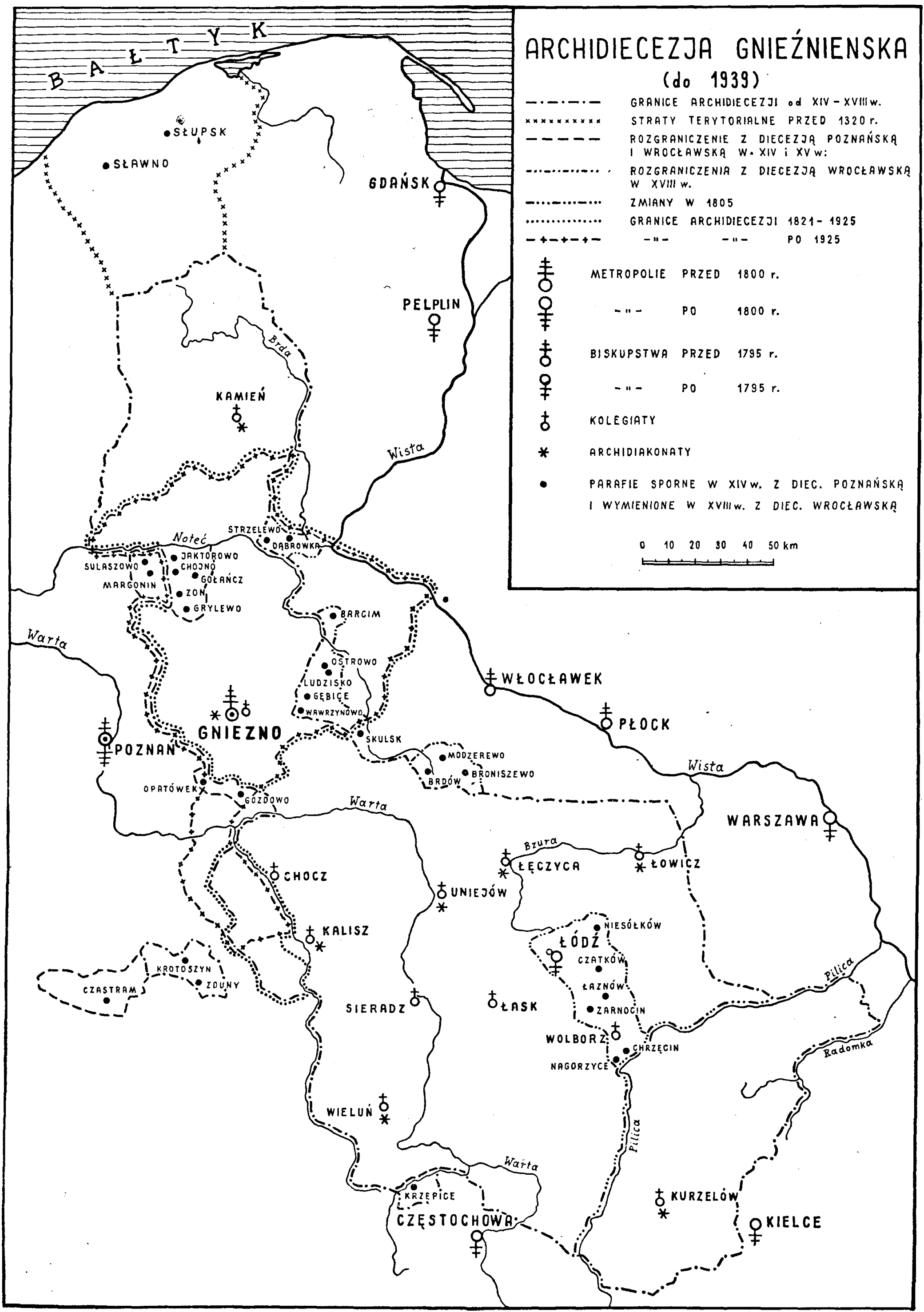

